\title{
Metabolic activity of bacterioplankton communities assessed by flow cytometry and single carbon substrate utilization
}

\author{
Joanne F. Jellett*, William K. W. Li, Paul M. Dickie, Azmeralda Boraie, Paul E. Kepkay \\ Biological Oceanography Section, Department of Fisheries and Oceans, Bedford Institute of Oceanography, PO Box 1006, \\ Dartmouth, Nova Scotia, Canada B2Y 4 A2
}

\begin{abstract}
During the summer of 1994, bacterioplankton abundance and metabolism were examined in seawater from Bedford Basin, Nova Scotia, Canada. Two new methods were applied to independently assess metabolic activity: (1) flow cytometric analysis of bimodal nucleic acid distributions in bacterioplankton stained with a novel fluorescent dye, and (2) utilization of single carbon substrates in Biolog GN Microplatesiu. Both sets of results were compared to bacterial production estimates obtained using a standard technique for ${ }^{3} \mathrm{H}$-thymidine and ${ }^{3} \mathrm{H}$-leucine incorporation. Flow cytometry quantified the relative abundance of the bactenoplankton cells with a high apparent nucleic acid content, which was expressed as an active cell index (ACI) of dividing and/or actively metabolizing cells. The ACI was positively correlated with sole carbon source utilization at 1,5 and $10 \mathrm{~m}(\mathrm{p}<0.05)$. Variations in ACI and sole carbon source utllization followed trends similar to, but could not be directly correlated with, bacterial production throughout the summer period. The new methods provided information that could not be obtained using the standard techniques for bacterial production. Instead, they yielded new and complementary information on the metabolic state of dividing and/or metabolizing cells and insight into the regulation of bacterial production.
\end{abstract}

KEY WORDS: Flow cytometry Nucleic acid content TO-PRO'M Biolog Tritiated leucine - Tritiated thymidine Cell cycle

\section{INTRODUCTION}

The introduction and exploitation of methods for estimating microbial biomass and production have proven that bacteria are important in marine ecosystems, decomposing and remineralizing as much as $50 \%$ of the daily primary production (Cole et al. 1988). Heterotrophic activity has commonly been determined from the short-term uptake of radiotracers and has been expressed as the rate of total carbon production or production cell ${ }^{-1}$. In conjunction with estimates of bacterial abundance, uptake rates have been used to determine biomass and specific growth rates of bacterioplankton populations. Shortcomings associated with

\footnotetext{
-Present address: c/o Jellett Biotek Ltd, INNOVAcorp، PO Box 790, Dartmouth, Nova Scotıa, Canada B2Y $3 Z 7$

E-mail: jjellett@nsrfc.ns.ca
}

this technique prompted Robarts \& Zoharty (1993) to suggest that complementary methods be used together to determine the environmental significance of bacterial production measurements.

During the development of a flow cytometric method for the enumeration of marine bacteria in seawater, Li et al. (1995) found that bacterioplankton stained with 2 nucleic acid-specific fluorochromes (TO-PRO'M-1 iodide and TOTO ${ }^{\mathrm{TM}}-1$ iodide) were distributed bimodally based on the relative abundance of nucleic acids: Group II had higher relative fluorescence (or apparent nucleic acid content) per cell than did Group I. The relative abundance of Group II bacterioplankton was positively correlated with the standing stock of chlorophyll $a$ in seawater samples from the Atlantic Ocean and the Mediterranean Sea. Furthermore, in a growth. experiment where a dilution technique (Ducklow et al. 1992) was used to reduce grazing pressure, about $75 \%$ 
of the increase in bacterioplankton cell numbers in one seawater sample could be attributed to Group II cells, showing a much higher potential for growth among Group II than Group I cells (Li et al. 1995). These findings lead to an important question: Can the relative abundance of Group II cells provide an assessment of bacterial metabolic activity that would complement bacterial production estimates obtained from tritiated leucine and thymidine $\left({ }^{3} \mathrm{H}\right.$-Tdr or ${ }^{3} \mathrm{H}$-leu) uptake?

To answer this question, flow cytometry and ${ }^{3} \mathrm{H}$-substrate uptake techniques were applied to seawater collected from Bedford Basin, Nova Scotia (Canada) during the summer of 1994 (Fig. 1). To advance the concept of complementary techniques, and to further pinpoint the role of bacterial metabolism in the regulation of bacterial production, an additional method was applied to the same seawater, i.e. sole carbon source utilization in Biolog GN Microplates ${ }^{\text {rM }}$ (Hayward, CA, USA) (Garland \& Mills 1991, Hollibaugh 1994).

The Biolog plates utilize tetrazolium violet as a redox dye to colorimetrically indicate the utilization of each of the 95 different carbon sources on each plate, and were developed for use in bacterial strain identification. Single point substrate utilization patterns in the Biolog system have been proposed as a measure of microbial community structure in aquatic, soil, rhizosphere (Garland \& Mills 1991) and marine (Hollibaugh 1994) habitats, as well as for the screening of bacterial consortia for the ability to degrade toxic substances (Gorden et al. 1993). This is the first report of the use of the Biolog plates to study patterns in substrate utilization in a single habitat over time.

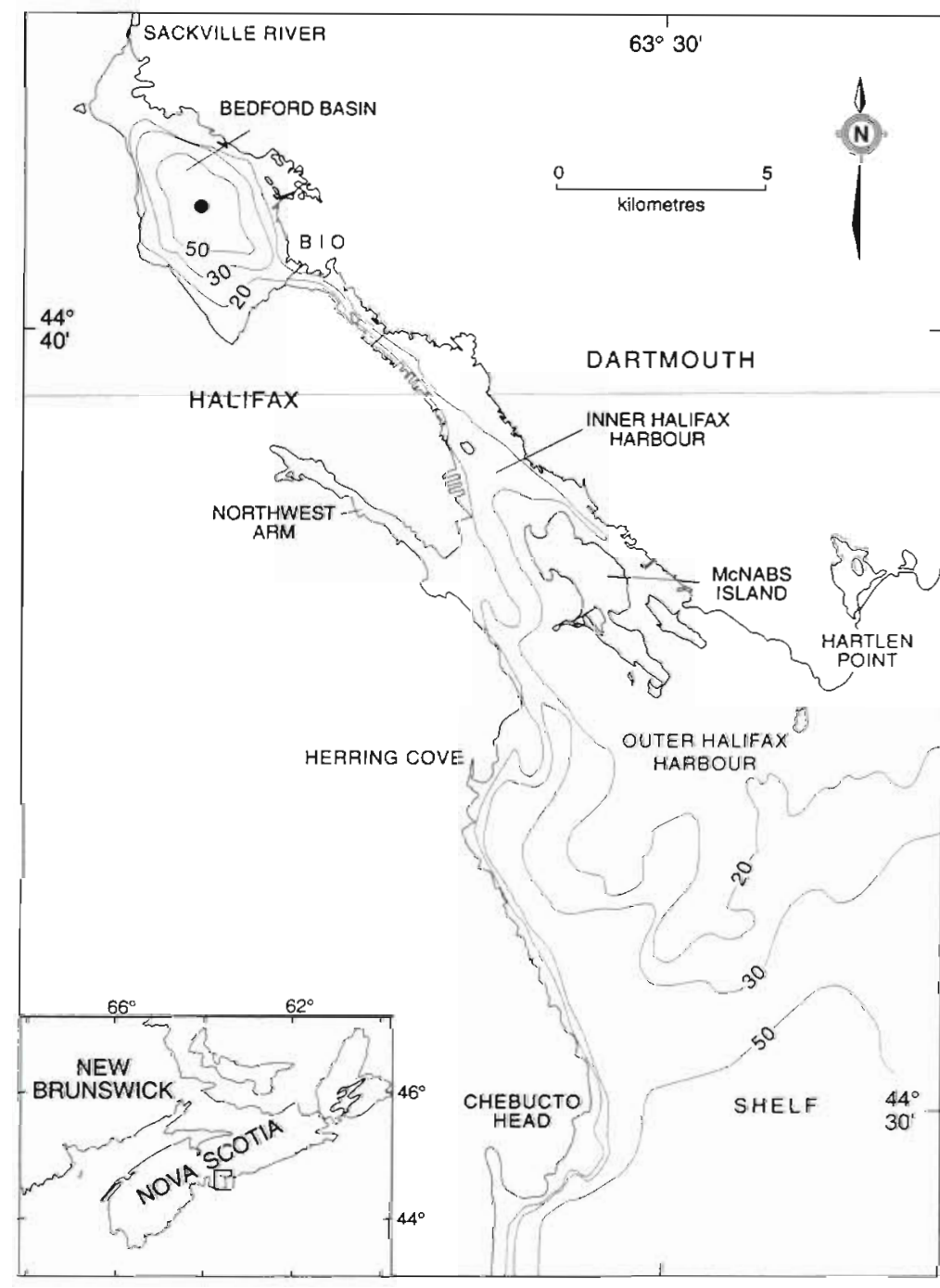

Fig. 1. Study site (1) in Bedford Basin, Nova Scotia, Canada, with enlarged view of the Halifax Harbour and Bedford Basin. BIO: Bedford Institute of Oceanography

\section{METHODS}

Sampling location, sample collection and filtration procedures. Seawater samples were collected weekly between June 1 and August 31, 1994 (Days 152 to 243 of the year), from the deepest site in Bedford Basin as indicated in Fig. 1 (lat. $44^{\circ} 41.3^{\prime}$ $\mathrm{N}$, long. $63^{\circ} 38.3^{\prime} \mathrm{W}$; maximum depth approx. $70 \mathrm{~m}$ ). The samples were obtained from a small vessel with Niskin casts to depths of $1,5,10$ and $60 \mathrm{~m}$ i standard hydrographic information was obtained with a Seabird CTD at the same time at the sample site. The temperature of each sample was obtained using a mercury thermometer when it arrived at the surface. On 1 additional day during the summer study (Aug 18), a depth profile of samples was taken at $5 \mathrm{~m}$ intervals from 1 to $65 \mathrm{~m}$.

Characteristics of the Bedford Basin include a salinity range of 28 to $32 \%$, a large allochthonous input of material from the surrounding municipality of HalifaxBedford-Dartmouth (population approx. 278000 ), as well as general terrestrial runoff, and freshwater input from the Sackville River (Fig. 1). Approximate total volume of this body of water is $510 \times 10^{6}$ $\mathrm{m}^{3}$, of which approximately $4.9 \%(24.8 \times$ $10^{6} \mathrm{~m}^{3}$ ) is tidal volume; the average depth is $31 \mathrm{~m}$ (Gregory et al. 1993). After collection, samples were quickly transported to the nearby Bedford Institute of Oceanography (Fig. 1) in dark brown (for ${ }^{3} \mathrm{H}$-Tdr and ${ }^{3} \mathrm{H}$-leu incorporation experiments) 
and white opaque (for all other tests) polyethylene bottles. Seawater for sheath fluid, dilution fluid and particle-free filtration controls (flow cytometry), as well as for preparation of bacterial culture medium and suspensions (bacterial cultures), and for bacterioplankton samples for preliminary testing was also obtained from the Bedford Basin via seawater intake lines at the Bedford Institute of Oceanography.

Bedford Basin seawater obtained on the same day as the samples was filtered through glass fiber filters (GF/F Whatman) and then pre-rinsed $0.22 \mu \mathrm{m}$ cellulose acetate membranes (Millipore). This filtrate is hereafter called filtered seawater (FSW).

Basic physical and biological measurements. Triplicate $3 \mathrm{ml}$ aliquots of the seawater samples from each depth were filtered (0.2 $\mu \mathrm{m}$ Millipore) and frozen at $-10^{\circ} \mathrm{C}$ for analysis of dissolved nutrients (nitrate/ nitrite, phosphate and silicate). An unfiltered aliquot from each depth was placed in a glass bottle and stored at room temperature until it was analyzed for salinity by refractometry. Additional triplicate $100 \mathrm{ml}$ aliquots from each depth were filtered through glass fiber filters (Whatman GF75) at less than 7 psi ( 0.483 bar) and the filters were stored in glass scintillation vials at $-10^{\circ} \mathrm{C}$ for later measurement of bulk chlorophyll (fluorometric assay of acetone extracts). Total chlorophylls, salinities and temperatures were also obtained from each CTD record.

Flow cytometry. Bacterioplankton samples from the 4 depths were stained and analyzed while fresh by flow cytometry on each collection day. Subsamples $(50 \mathrm{ml})$ from each depth were fixed for $1 \mathrm{~h}$ in the dark at $5^{\circ} \mathrm{C}$ with $1 \%$ (final) paraformaldehyde (Marivac Ltd, Halifax, NS). Paraformaldehyde was prepared according to the method of Campbell (1993); this fixative was filtered (0.22 $\mu \mathrm{m}$ Millipore) as it was added to each sample. Duplicate $2 \mathrm{ml}$ fixed samples were also frozen at $-70^{\circ} \mathrm{C}$ after fixation for $10 \mathrm{~min}$ at room temperature.

The nucleic acid stain TO-PRO-1 iodide ${ }^{\mathrm{TM}}$ (TP1) (Molecular Probes, Inc., Eugene, OR, USA) was used at $3 \mu \mathrm{M}$ final concentration. Subsamples $(1 \mathrm{ml})$ of fixed seawater were stained for 5 to $15 \mathrm{~min}$ in the dark. Staining was immediately preceded by the addition of sufficient filter-sterilized (0.2 $\mathrm{\mu m}$ Millipore) $10 \%$ Triton-X100 (TX) (BDH) stock solution to give a final concentration of $0.1 \% \mathrm{TX}$ in each sample. See Li et al. (1995) for full details of the staining method. Samples and FSW controls were prepared in parallel.

Flow cytometry was carried out on a Becton Dickinson (Mississauga, ON, Canada) FACSort ${ }^{\text {TM }}$ instrument with a Cyonics $15-\mathrm{mW}$, 488-nm, air-cooled, argon-ion laser. A minimum of 2 replicates of each sample were examined. Detection was primarily in channel FL1 (green fluorescence) as described by Li et al. (1995). Calibration of the sample flow rate was performed rou- tinely as described by the instrument manufacturer and also by using $0.5 \mu \mathrm{m}$ beads stained with fluorescein (Polysciences, Inc., Warrington, PA). Listmode data were analyzed to yield abundance estimates with the associated LYSYS ${ }^{\mathrm{TM}}$ II (Becton Dickinson) software or WinMDI (@ Joseph Trotter 1994: trotter@scripps.edu). Total abundance, as well as relative abundance of Groups I and II bacterioplankton as described by Li et al. (1995), was obtained. In cases where bimodal peaks were not clearly separated on the basis of green fluorescence, the data were analyzed by non-linear curve fitting to a sum of lognormal distributions (Li 1990). For comparison of green fluorescence to amount of nucleic acid per cell, fixed preparations of calf thymocyte nucleii (Riese Enterprises, CA) were stained with TP1 as described above except $10 \mathrm{nM}$ (final) stain concentration was used to bring the fluorescence into the same detector range as the bacteria.

The active cell index (ACI) was calculated by dividing the number of high fluorescence (Group II) bacterioplankton in each sample with the total abundance and expressed as a percent.

Bacterial cultures. Preliminary experiments were performed using a cultured marine bacterial strain designated C321a which was isolated from natural seawater and maintained on marine agar (Difco) slants at $5^{\circ} \mathrm{C}$. Subcultures were grown at room temperature overnight in $0.2 \mu \mathrm{m}$ sterile-filtered LIB-X broth (Baross et al. 1974). A $1 \mathrm{ml}$ aliquot of the overnight culture was used to inoculate another $50 \mathrm{ml}$ of filtered LIB-X, and the cultures were grown on a reciprocal shaker for $26 \mathrm{~h}$. At $0,4,7$ and $26 \mathrm{~h}, 10 \mathrm{ml}$ aliquots were removed from the culture tube, fixed with $1 \%$ (final) formalin $(\mathrm{BDH})$, and spun at $5000 \times g$ in a benchtop clinical centrifuge. The supernatant fluid was removed, the pellet was resuspended in $10 \mathrm{ml}$ of $0.2 \mu \mathrm{m}$ FSW, and the samples were diluted in FSW, stained, and examined by flow cytometry as described below. The optical density of each was measured at $0,4,7,15$ and $26 \mathrm{~h}$.

Carbon source utilization in the Biolog plates. Aliquots $(150 \mu \mathrm{l})$ of freshly collected, unfiltered seawater from each depth were inoculated aseptically into the individual wells of 5 replicate Biolog plates. The plates were incubated at $5^{\circ} \mathrm{C}$ (all depths) between Days 152 and 201 (days of the year), and at the temperature closest to ambient of $5,10,15$ or $20^{\circ} \mathrm{C}$ between Days 208 and 243. The colour absorbance of each was read spectrophotometrically at $540 \mathrm{~nm}$ using a microplate reader (Molecular Devices, Menlo Park, CA) after $14 \mathrm{~d}$. Most substrates showed maximal colour development by $14 \mathrm{~d}$ at $5^{\circ} \mathrm{C}$. Those containing the lowest and highest values were eliminated, leaving triplicate spectrophotometric readings for each depth. The time zero reading for each well was subtracted from each subsequent reading for that well, and the resulting 
absorbances calculated for each substrate were expressed as percent increase in absorbance over that recorded at time zero. The individual substrates were grouped into carbohydrates (28), carboxylic acids (24), amino acids (20), polymers (5), aromatic chemicals (4), amides (3), phosphorylated chemicals (3), amines (3) esters (2), alcohols (2), and brominated chemicals (1) (Garland \& Mills 1991). To determine the most highly utilized individual substrates and groups of substrates, utilization was averaged over Days 152 to 201 and 208 to 243 , and then ranked as follows: not utilized, 0 to $50 \%$ (rank 1); low utilization, 51 to $100 \%$ (rank 2); high utilization, 101 to $200 \%$ (rank 3); very high utilization, $>200 \%(\operatorname{rank} 4)$.

Leucine and thymidine uptake experiments. Labelled thymidine and leucine were obtained from ICN, Costa Mesa, CA $\left(4,5-{ }^{3} \mathrm{H}\right.$-L-leucine, cat. no. 20036, $74 \mathrm{Ci} \mathrm{mmol}^{-1}$; methyl- ${ }^{3} \mathrm{H}-\mathrm{Tdr}$, cat no. 2406005 , $67 \mathrm{Ci} \mathrm{mmol}^{-1}$ ). Leucine and thymidine uptake experiments were performed concurrently, and immediately after the water was returned to the Bedford Institute. The method was performed according to $\mathrm{Li}$ et al. (1993), except that $30 \mathrm{ml}$ samples from each depth were incubated in $50 \mathrm{ml}$ clear Nalgene polycarbonate centrifuge bottles ( 1 bottle per substrate) in the dark in water baths set at the in situ temperature for each depth as measured during sample collection on that day. After addition of either $5 \mathrm{nM}{ }^{3} \mathrm{H}$-Tdr or $10 \mathrm{nM}{ }^{3} \mathrm{H}$ leu (final concentration) to the seawater in the incubation bottles followed by mixing, triplicate $4 \mathrm{ml}$ samples were immediately withdrawn and filtered through $0.2 \mu \mathrm{m}$ nuclepore filters with less than 7 psi vacuum pressure. Each filter was then rinsed twice with the same volume of $0.2 \mu \mathrm{m}$ filtered seawater, dried by suction filtration, folded (with the collected material inside) and stored in labelled glassine philatelic envelopes at $-10^{\circ} \mathrm{C}$ until extraction. The remaining sample in each centrifuge bottle was then incubated at the in situ temperature for $1 \mathrm{~h}$, at which time 3 additional $5 \mathrm{ml}$ aliquots were removed and filtered. The filters were then rinsed, dried, folded and frozen as for the time zero samples.

Extraction of ${ }^{3} \mathrm{H}$-Tdr-labelled macromolecules from cells was performed by the cold TCA method according to Li et al. (1993) except that filters and macromolecules were dissolved by heating for $30 \mathrm{~min}$ with $0.25 \mathrm{ml}$ of Hyamine $\mathrm{OH}(\mathrm{BDH})$. The ${ }^{3} \mathrm{H}$-leu-labelled macromolecules were extracted using the hot TCA extraction method as follows: filters were heated at $90^{\circ} \mathrm{C}$ for 20 min with $5 \mathrm{ml}$ of $5 \%$ TCA. The tubes were then cooled to room temperature, and the contents of each tube (including the filter) were filtered through a glass fiber filter (Whatman GF/F) at 7 psi vacuum. The tubes were each rinsed twice with $2 \mathrm{ml} 5 \%$ TCA which was then also filtered through the same glass fiber fil- ters. The filters were then each rinsed with $1 \mathrm{ml}$ of $95 \%$ ethanol. The glass fiber filter and the nuclepore filter were then transferred together to a scintillation vial and dissolved as for the ${ }^{3} \mathrm{H}-\mathrm{Tdr}$ filters above. After cooling to room temperature, $50 \mu \mathrm{l}$ of glacial acetic acid $(\mathrm{BDH})$ and $10 \mathrm{ml}$ of Ecolite scintillation fluor (Fisher Scientific, Detroit, MI, USA) were added to each vial. Liquid scintillation counts for both types of extracts were obtained on a Beckman LS-3133T spectrometer corrected for quenching by the external standards ratio method.

Theoretical conversion factors of $1.7 \times 10^{18} \mathrm{cells} \mathrm{mol}^{-1}$ ${ }^{3} \mathrm{H}-\mathrm{Tdr}$ (Simon \& Azam 1989) and $20 \mathrm{fg} \mathrm{C}^{\mathrm{C}} \mathrm{Cell}^{-1}$ (Ducklow \& Carlson 1992) were used to estimate heterotrophic bacterioplankton production from ${ }^{3} \mathrm{H}-\mathrm{Tdr}$ incorporation. Calculation of bacterial protein production was estimated using the factors recommended by Simon \& Azam (1989) of $3595 \mathrm{~g}$ protein or $3091.7 \mathrm{~g} \mathrm{C}$ $\mathrm{mol}^{-1}$ of ${ }^{3} \mathrm{H}$-leu incorporated. Total productivity was determined as the mean of the estimates from the 2 substrates. Cell-specific productivity was estimated by dividing total productivity per liter by the number of bacteria per liter obtained by flow cytometry.

A growth experiment was performed on a $1 \mathrm{~m}$ and a $60 \mathrm{~m}$ sample according to the method of Ducklow et al. (1992), where each sample was diluted $(0.1 \mathrm{v} / \mathrm{v})$ to reduce grazing pressure. Diluted samples and undiluted control seawater from each depth were analyzed for ${ }^{3} \mathrm{H}$ - Tdr and ${ }^{3} \mathrm{H}$-leu incorporation as above at time zero and at $3 \mathrm{~h}$ intervals for $24 \mathrm{~h}$. Bacterial counts were obtained by standard epifluorescent microscopy with DAPI as in Li et al. (1995) at each time interval.

Statistical analysis. The ACI and the utilization patterns from Biolog carbon sources that showed high to very high average utilization over several depths were compared, using single or multiple pairwise correlations (Systat), to each other and to other variables obtained on the same sample date including bacterial abundance, individual (from ${ }^{3} \mathrm{H}-\mathrm{Tdr}$ or ${ }^{3} \mathrm{H}$-leu), total and cell specific bacterial production, chlorophyll a, nutrients, water and air temperature, and precipitation. Substrate utilization in the Biolog plates was also averaged for each day for each general class of substrates, and this average utilization was compared with other variables using multiple pairwise correlations.

\section{RESULTS}

\section{Physical and biological measurements from field samples}

During the summer sampling period of this study, the seawater collected from $60 \mathrm{~m}$ was different in many respects from that obtained from the upper 1, 5 and 
$10 \mathrm{~m}$ depths. At 1,5 and $10 \mathrm{~m}$, chlorophyll a ranged from about 1.0 to $10.0 \mathrm{\mu g} \mathrm{l}^{-1}$, temperatures from 5 up to $22^{\circ} \mathrm{C}$, salinities from 29 to $31 \%$, and nutrient levels were generally lower $(<0.6 \mu \mathrm{M}$ nitrate, $<1 \mu \mathrm{M}$ phosphate and 2 to $10 \mu \mathrm{M}$ silicate) than those found at $60 \mathrm{~m}$. In comparison, water from $60 \mathrm{~m}$ was consistently low in chlorophyll $\left(<1.0 \mu \mathrm{g} \mathrm{l}^{-1}\right)$, remained below $5^{\circ} \mathrm{C}$, had consistent salinities around $31 \%$, and had higher dissolved nutrient leveis, especially nitrate ( 8 to $12 \mu \mathrm{M}$ nitrate, 1 to $3 \mu \mathrm{M}$ phosphate, and 15 to $35 \mu \mathrm{M}$ silicate), than did the upper depths. There was a stable thermocline and pycnocline, both of which remained between 5 and $15 \mathrm{~m}$ throughout the period sampled. Precipitation was generally low (average $<1 \mathrm{~mm}$ daily); higher amounts $(10 \mathrm{~mm}$ or more) were recorded on only 3 days in June, 1 in July and and 4 in August.

\section{Flow cytometry}

Coefficients of variation of counts from FSW particlefree control samples were always less than $1 \%$ and often less than $0.5 \%$ of the individual population counts and therefore were not used in the calculation of bacterial abundance. Furthermore, replication of samples was extremely tight (coefficient of variation generally $<1 \%$, always $<5 \%$ ).

Bimodal distributions based on different nucleic acid content (Groups I and II) were observed in samples of Bedford Basin seawater containing heterogeneous bacterioplankton, as well as in pure bacterial cultures grown in the laboratory. When stained with TP1 and analyzed by flow cytometry as described above, Group II always had a higher intensity of emitted green fluorescence celli ${ }^{-1}$, and hence higher apparent nucleic acid content cell ${ }^{-1}$, than Group I.

Isolated calf thymocyte nucleii, which are from eukaryotic cells with tightly regulated $1 n$ and $2 n$ stages, also produced 2 subpopulations based on mean fluorescence per nucleus: a large peak containing $1 \mathrm{n}$ nuclei and a smaller peak with higher fluorescence containing $2 n$ nucleii. Under the flow cytometry conditions employed in this study, the ratio of green fluorescence intensity between populations of $2 n$ and $1 n$ genome size was $1.98 \pm 0.09$. Therefore, in this study, the ratio of fluorescence was essentially equivalent to the ratio of total nucleic acid content.

In preliminary experiments with pure bacterial cultures (Table 1), the relative fluorescence (nucleic acid) cell $^{-1}$ of each group varied during the growth cycle as did the ratio of the relative abundance of Group II bacteria (ACI). The majority ( 60 to $85 \%$ ) of bacteria in exponential growth were Group II cells, each of which contained around 2 to 5 times more nucleic acid cell ${ }^{-1}$ than the Group I population (Table 1). In late stationary
Table 1. Differences between Group I (low nucleic acid cell-1 ${ }^{-1}$ ) and Group II (high nucleic acid content cell ${ }^{-1}$ ) subpopulations in pure cultures as determined by staining with TO-PRO ${ }^{\text {Mi- }}-1$ and analysis by flow cytometry

\begin{tabular}{|ccc|}
\hline Time (h) & $\begin{array}{c}\text { Ratio of fluorescence } \\
\text { cell }^{-1}\end{array}$ (Group II:I) & $\begin{array}{r}\text { Percent of Group II } \\
\text { cells (\% ACI) }\end{array}$ \\
\hline 0 & 3.19 & 76 \\
4 & 5.81 & 85 \\
7 & 1.56 & 61 \\
26 & 1.08 & 8 \\
\hline
\end{tabular}

phase, however, almost all (99\%) of the cells were characterized as Group I cells, and the Group II cells that were present had only marginally higher levels of nucleic acids cell ${ }^{-1}$.

The bimodal nucleic acid distributions of stained bacterioplankton from Bedford Basin varied over time and depth in both relative abundance and fluorescence cell $^{-1}$. Fluorescence histograms showing the distribution of bacterioplankton from a depth profile of the study site into Group I and II cells are shown in Fig. 2. On the basis of the bimodal nucleic acid distributions, the water column in Bedford Basin could be subdivided into 3 zones: surface water ( 1 to $25 \mathrm{~m}$ ), midwater $(30$ to $50 \mathrm{~m}$ ) and benthic boundary layer ( 55 to $65 \mathrm{~m}$ ). Abundance and relative fluorescence cell ${ }^{-1}$ over this depth profile are shown in Fig. 3A, B. The fluores-

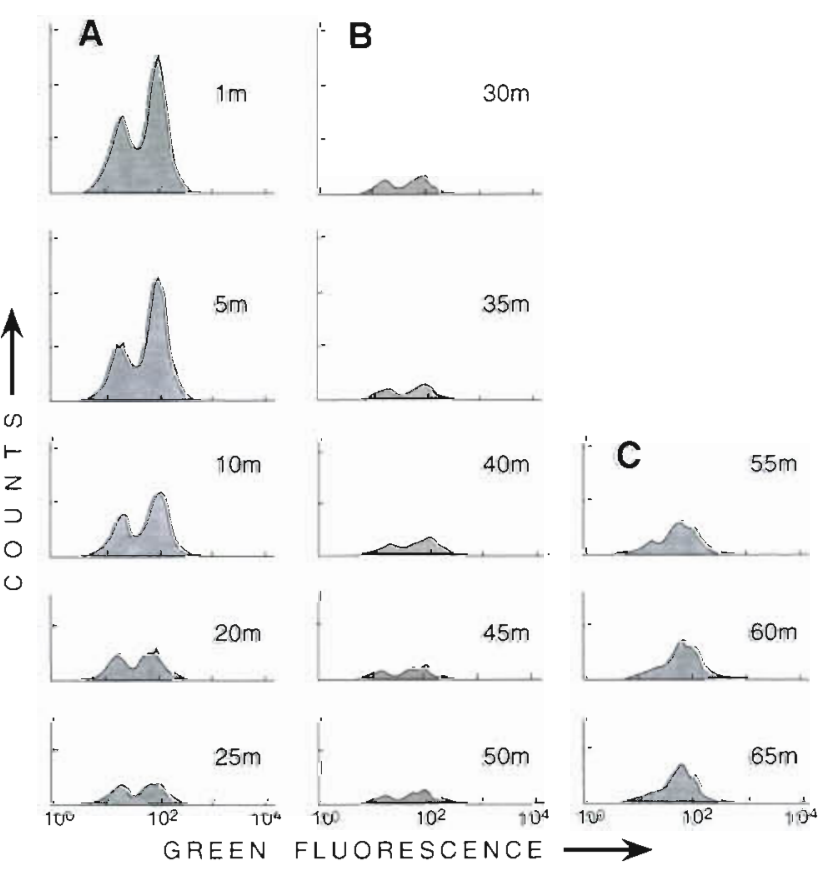

Fig. 2. Distribution of fluorescently stained cells into 2 subpopulations for a depth profile obtained at the study site on 1 day. Samples are divided into surface (A), mid-water (B) and benthic boundary (C) layers 

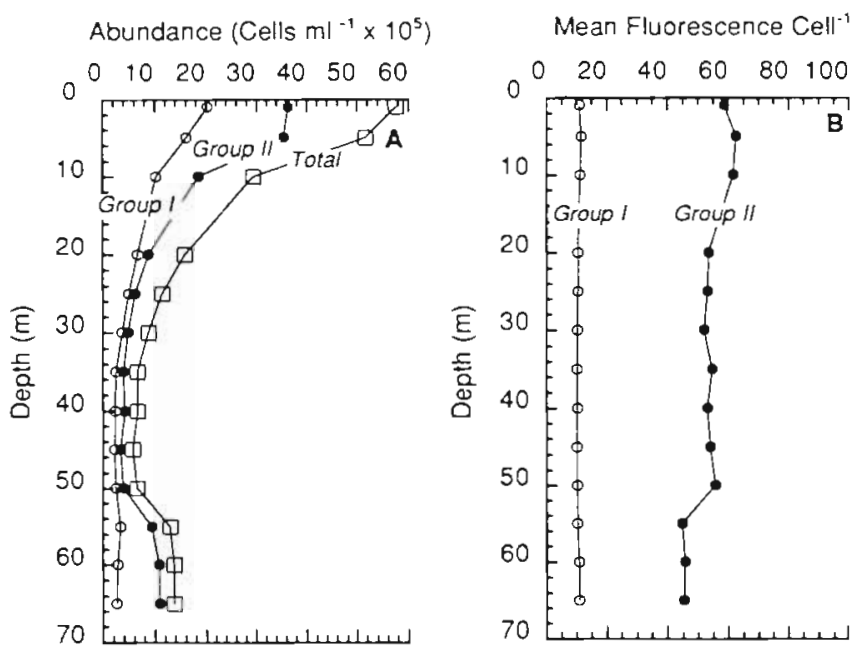

Fig. 3. Relative abundance (A) and fluorescence $\mathrm{cel}^{-1}(B)$ of Group I llow fluorescence, of and Group II (high fluorescence, -) subpopulations identified by flow cytometry in a depth profile of bacterioplankton samples stained with TOPRO-1-iodide ${ }^{1 \mathrm{M}}$. (口) Total abundance of bacteria. All samples were taken at thesame location on the same day

cence cell ${ }^{-1}$ of the Group I cells was relatively constant over depth, while that of Group II cells decreased with depth (Fig. 3B). The Group II bacteria contained a mean of $5.04 \pm 0.5(n=13)$ times more nucleic acid cell $^{-1}$ based on fluorescence, although Group II cells from depths above $20 \mathrm{~m}$ had a ratio slightly greater than 5 and those from depths below $50 \mathrm{~m}$ had a ratio of slightly less than 5 .

Examination of the fluorescence histograms of bacterioplankton obtained from 4 depths over the study period showed little temporal variation in the fluorescence cell ${ }^{-1}$, but weekly variation was observed in the relative abundance of the Group II cells (ACI), as well as in the total bacterioplankton abundance, both of which are shown for each respective depth in Figs. 4 to 7. In a randiom set of Bedford Basin seawater samples taken at different times, the Group II bacterioplankton contained $4.97 \pm 0.98(\mathrm{n}=9)$ times more nucleic acid cell $^{-1}$ than the Group I cells.

\section{Carbon source utilization in the Biolog plates}

When utilization of each individual substrate in the Biolog plates was ranked by averaging over the summer study period, it was found that only a small group was consistently highly utilized (Table 2). Ranking by averaging the different substrates within each group of substrates showed that the most important substrate groups during this study period were esters, followed by the polymers and the brominated chemicals
(Table 3). Generally, the individual substrates showed similar average levels of utilization over all depths (i.e. substrates were either unutilized at all depths or were utilized to similar levels over all depths). However, when normalized to the smaller inoculum size, substrate utilization at $60 \mathrm{~m}$ was found to be much higher than at the other 3 surface depths.

Utilization of most substrates increased when water temperatures were higher and incubation temperatures were ambient. Of the individual substrates, none of the carbohydrates, amines, or amides were highly utilized regardless of incubation temperature. Aconitic acid, citric acid, D-gluconic acid (carboxylic acids), and methylpyruvate (esters) were the only substrates which were highly utilized regardless of incubation temperature. Another small group of substrates went from low to either high or very high utilization when water temperatures at 1,5 and $10 \mathrm{~m}$ were much higher and incubation temperatures for the Biolog plates were close to ambient. Only one substrate, a polymer, Tween 40 , was unutilized when the plates were incubated at $5^{\circ} \mathrm{C}$ but highly utilized when incubation temperatures were higher.

Leucine and thymidine, both substrates on the Biolog plates in the amino acid and aromatic categories respectively, were not utilized at all when incubation temperatures were $5^{\circ} \mathrm{C}$. Thymidine utilization increased to low levels, while leucine utilization in-

Table 2. Average utilization across all depths of the most highly utilized (rank 2 or higher) of the 95 Biolog substrates by bacterial consortia from Bedford Basin seawater. Ranking of utilization as follows: not utilized, $0-50 \%$ above blank (rank 1); low utilization, 51-100\% (rank 2); high utilization, $101-200 \%$ (rank 3); very high utilization, $>200 \%$ (rank 4)

\begin{tabular}{|llc|}
\hline Group & Substrate utilized & $\begin{array}{c}\text { Level of } \\
\text { utilization }\end{array}$ \\
\hline Amino acids & L-ananyl-glycine & $2-3$ \\
& L-glutamic acid & $2-3$ \\
& Glutamic acid & $2-3$ \\
& L-serine & $2-3$ \\
& L-threonine & $2-3$ \\
Carbohydrates & D-galactose & $2-3$ \\
& Sucrose & $2-3$ \\
Carboxylic acids & D-trehalose & $2-3$ \\
& cis-aconitic acid & 3 \\
& Citric acid & 3 \\
Polymers & D-gluconic acid & $3-4$ \\
Aromatic chemical & alpha-ketoglutaric acid & $2-3$ \\
Phosphorylated & Glycogen & $2-3$ \\
chemicals & Glucose-1-phosphate & $2-3$ \\
Esters & & \\
& Methylpyruvate & $3-4$ \\
\hline
\end{tabular}


Table 3. The utilization of substrate groups over Days 152 to 201 of the year when Biolog plates were incubated at $5^{\circ} \mathrm{C}$ and Days 208 to 243 of the year when incubation temperatures were ambient. Utilization of substrates within each group was averaged and then ranked by level of utilization (see Table 2 legend for ranking scheme). Number of individual substrates in each group is shown in parentheses: All grps: all substrates except control; $\mathrm{CHO}$ : carbohydrates; $\mathrm{COOH}$ : carboxylic acids; br ch: brominated chemicals; aa: amino acids; ar ch: aromatic chemicals; phosph: phosphorylated chemicals

\begin{tabular}{|c|c|c|c|c|c|c|c|c|}
\hline \multirow[t]{3}{*}{ Substrates } & \multicolumn{8}{|c|}{ Substrate utilization level } \\
\hline & \multicolumn{4}{|c|}{$5^{\circ} \mathrm{C}$ incubation } & \multicolumn{4}{|c|}{ Ambient incubation } \\
\hline & $1 \mathrm{~m}$ & $5 \mathrm{~m}$ & $10 \mathrm{~m}$ & $60 \mathrm{~m}$ & $1 \mathrm{~m}$ & $5 \mathrm{~m}$ & $10 \mathrm{~m}$ & $60 \mathrm{~m}$ \\
\hline All grps (95) & 1 & 1 & 1 & 1 & 3 & 3 & 2 & 2 \\
\hline Polymers (5) & 2 & 2 & 2 & 2 & 3 & 3 & 2 & 2 \\
\hline $\mathrm{CHO}(28)$ & 1 & 1 & 1 & 1 & 3 & 3 & 1 & 1 \\
\hline Esters (2) & 3 & 3 & 3 & 3 & 4 & 4 & 3 & 3 \\
\hline $\mathrm{COOH}\{24\}$ & 1 & 1 & 1 & 1 & 2 & 3 & 1 & 1 \\
\hline Br ch (1) & 2 & 2 & 2 & 2 & 3 & 3 & 2 & 2 \\
\hline Amides (3) & 1 & 1 & 1 & 1 & 1 & 1 & 1 & 1 \\
\hline Aa (20) & 1 & 2 & 1 & 1 & 3 & 3 & 3 & 2 \\
\hline $\operatorname{Arch}(4)$ & 1 & 1 & 1 & 1 & 3 & 3 & 2 & 2 \\
\hline Amines (3) & 1 & 1 & 1 & 1 & 1 & 1 & 1 & 1 \\
\hline Alcohols (2) & 1 & 1 & 1 & 1 & 3 & 3 & 2 & 2 \\
\hline Phosph (3) & 1 & 1 & 1 & 1 & 2 & 2 & 1 & 1 \\
\hline
\end{tabular}

creased to moderate levels, at the higher (ambient) temperatures of incubation but only for the 1 and $5 \mathrm{~m}$ samples. However, patterns of utilization of these 2 substrates in the Biolog plates did not correlate with

Table 4. Mean total productivity (ng Carbon $\mathrm{l}^{-1} \mathrm{~h}^{-1}$ ) for Bedford Basin heterotrophic bacteria at 4 depths as measured by tritiated thymidine and leucine uptake

\begin{tabular}{|c|c|c|c|c|}
\hline \multirow[t]{2}{*}{ Substrate } & \multicolumn{4}{|c|}{ Mean total productivity $( \pm S D)$} \\
\hline & $1 \mathrm{~m}$ & $5 \mathrm{~m}$ & $10 \mathrm{~m}$ & $60 \mathrm{~m}$ \\
\hline${ }^{3} \mathrm{H}-\mathrm{Tdr}$ & $\begin{array}{l}1045.98 \\
(713.30)\end{array}$ & $\begin{array}{c}765.57 \\
(587.75)\end{array}$ & $\begin{array}{c}341.95 \\
(436.36)\end{array}$ & $\begin{array}{c}50.86 \\
(54.50)\end{array}$ \\
\hline${ }^{3} \mathrm{H}$-leu & $\begin{array}{l}1357.33 \\
(837.73)\end{array}$ & $\begin{array}{c}1507.21 \\
(1303.04)\end{array}$ & $\begin{array}{r}906.38 \\
(1854.74)\end{array}$ & $\begin{array}{c}123.91 \\
(254.58)\end{array}$ \\
\hline
\end{tabular}

Table 5. Mean cell-specific productivity (ng carbon cell ${ }^{-1} \mathrm{~h}^{-1}$ $\times 10^{-8}$ ) for Bedford Basin heterotrophic bacteria at 4 depths as measured by tritiated thymidine and leucine uptake

\begin{tabular}{|lcccc|}
\hline \multirow{2}{*}{ Substrate } & \multicolumn{5}{c}{ Mean cell-specific productivity } & $( \pm \mathrm{SD})$ \\
& $1 \mathrm{~m}$ & $5 \mathrm{~m}$ & $10 \mathrm{~m}$ & $60 \mathrm{~m}$ \\
\hline${ }^{3} \mathrm{H}-\mathrm{Tdr}$ & 27.90 & 21.52 & 12.47 & 3.97 \\
& $(20.05)$ & $(20.41)$ & $(18.70)$ & $(4.57)$ \\
& & & & \\
${ }^{3} \mathrm{H}-\mathrm{leu}$ & 45.10 & 42.12 & 28.15 & 9.18 \\
& $(40.49)$ & $(37.74)$ & $(49.82)$ & $(19.47)$ \\
& & & & \\
\end{tabular}

production estimates from tritiated leucine and thymidine uptake $(\mathrm{p}<0.5)$.

Patterns of individual substrate utilization over time at each depth were not correlated statistically to bacterial abundance, ACI, or productivity estimates using tritiated substrates, but the patterns of utilization showed clear trends of similarity to the other indices of bacterial metabolic activity (panels $C$ and $D$ of Figs. 4 to 7 ) when plates were incubated at $5^{\circ} \mathrm{C}$. Temporal utilization patterns of the highly utilized substrates and the average groups of substrates were generally correlated with each other $(p<$ 0.5 to 0.05 ) within each depth. Similarly, Biolog utilization patterns of bacterial consortia from 1 , 5 and $10 \mathrm{~m}$ were correlated with each other but not with those from the $60 \mathrm{~m}$ sample $(\mathrm{p}<0.05)$.

\section{${ }^{3} \mathrm{H}$-thymidine and ${ }^{3} \mathrm{H}$-leucine uptake}

Patterns of total and cell-specific bacterial productivity over time at each of 4 depths are shown in panels $C$ and D of Figs. 4 to 7 . Total production values over all depths estimated using ${ }^{3} \mathrm{H}-\mathrm{Tdr}$ varied between 0 and $2400 \mathrm{ng} \mathrm{C}^{-1} \mathrm{~h}^{-1}$, with a mean of

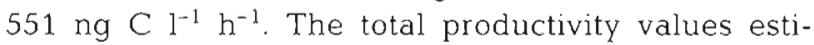
mated using ${ }^{3} \mathrm{H}$-leu were slightly higher, and ranged

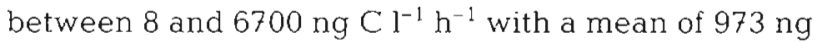
$\mathrm{C}^{-1} \mathrm{~h}^{-1}$ Mean total and cell-specific productivity for bacterioplankton from each depth over the summer sampling period are shown in Tables 4 \& 5 respectively. Estimates of bacterial production in different marine habitats cover a range from 2 to $119 \mathrm{mg} \mathrm{C} \mathrm{m}^{-3}$ $\mathrm{d}^{-1}$ (Ducklow \& Carlson 1992). The mean total productivity estimated in Bedford Basin is within this range and agrees with estimates from other coastal waters (reviewed in Ducklow \& Carlson 1992).

Further evidence of differences between the surface $(1,5$ and $10 \mathrm{~m}$ ) samples and the $60 \mathrm{~m}$ samples can be seen in Fig. 8. When seawater from $1 \mathrm{~m}$ was diluted $10-$

Legend for Figs. 4 to 7: (A) Chlorophyll measurements obtained from CTD trace. (B) Bacterioplankton abundance determined by flow cytometry (O). (C) Average total substrate utilization in Biolog GN Microplates ${ }^{\mathrm{IM}}$ incubated at $5^{\circ} \mathrm{C}(\mathrm{O})$. (D) Mean total productivity measured by tritiated leucine and thymidine uptake $(O)$; bars represent the range of estimates obtained by the 2 radiotracer methods. (E) Mean cell-specific productivity measured by tritiated leucine and thymidine uptake (O); bars represent the range of estimates obtained by the 2 radiotracer methods. For $B, C, D$, and $E$, active cell index $\left(\mathrm{ACI}_{;}\right)$was determined by flow cytometry. Standard deviations of measurements made by flow cytometry were too small to be visible 

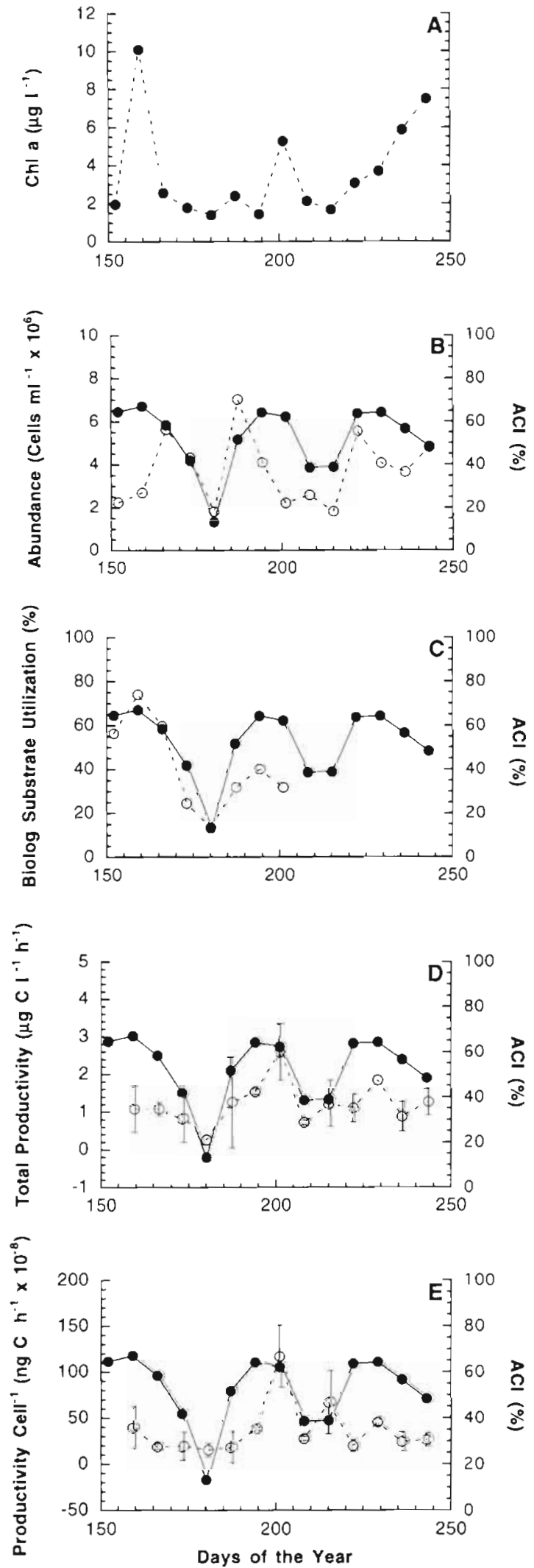

Fig. 4. Measurements of chlorophyll $a$ and bactenal activity in Bedford Basin seawater from $1 \mathrm{~m}$
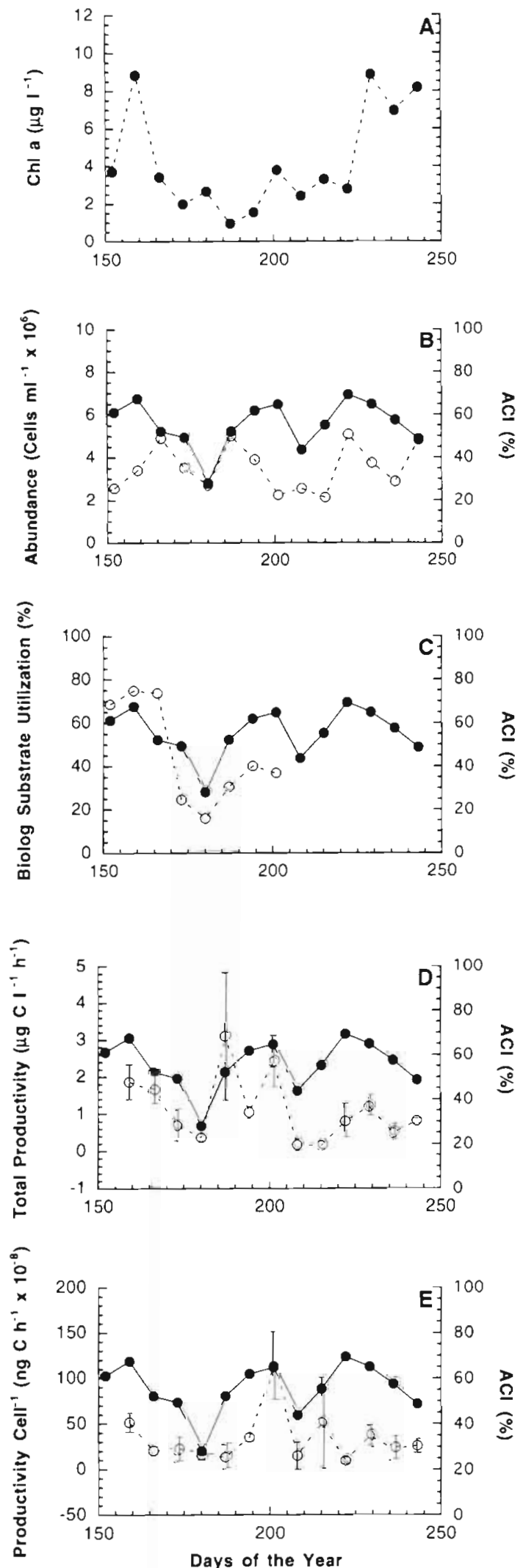

Fig. 5. Measurements of chlorophyll a and bacterial activity in Bedford Basin seawater from $5 \mathrm{~m}$ 

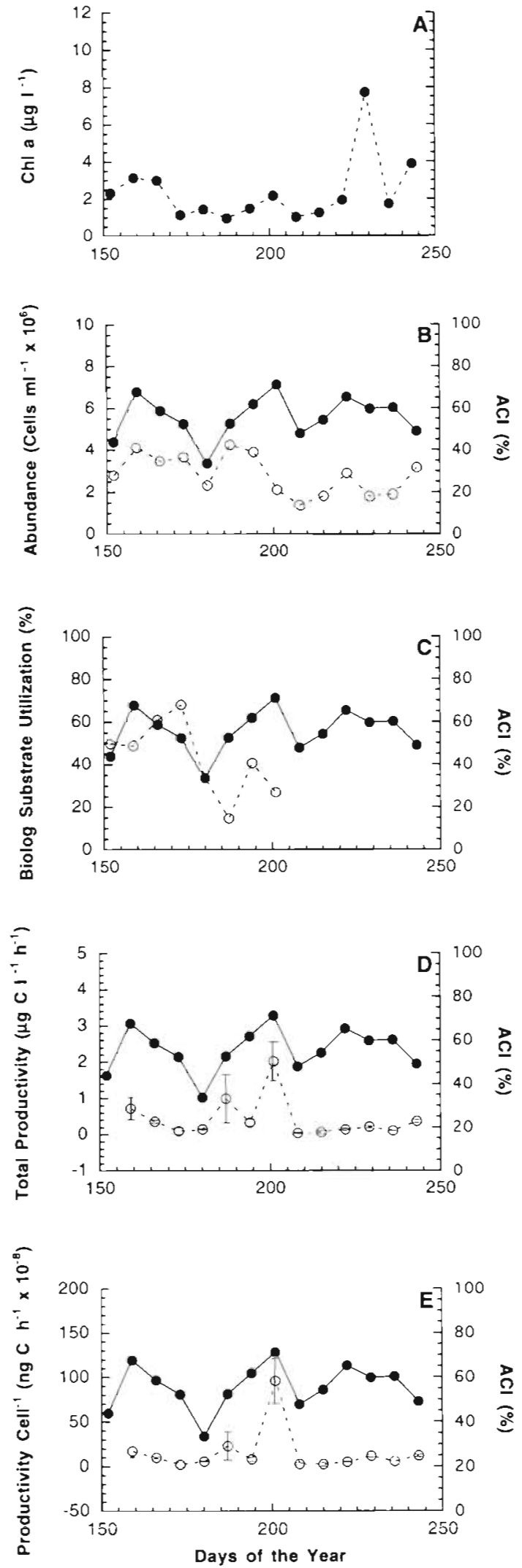

Fig. 6. Measurements of chlorophyll a and bacterial activity in Bedford Basin seawater from $10 \mathrm{~m}$
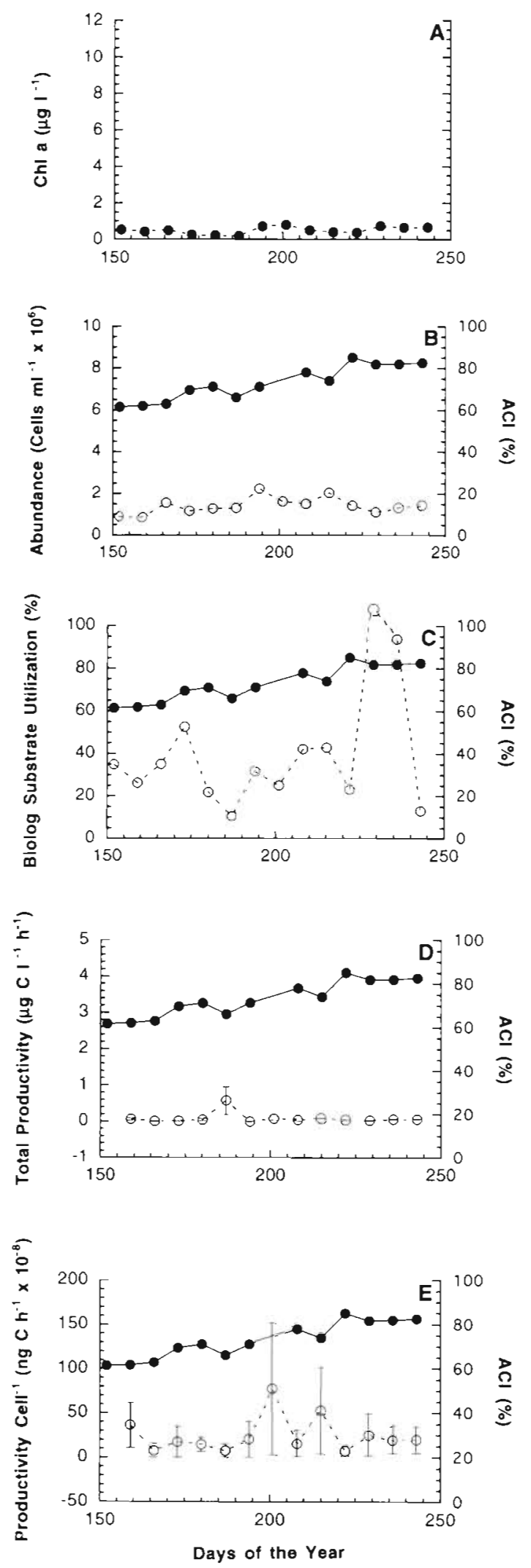

Fig. 7. Measurements of chlorophyll a and bacterial activity in Bedford Basin seawater from $60 \mathrm{~m}$ 
fold to reduce the effect of grazing pressure, bacterioplankton took up increasingly greater amounts of ${ }^{3} \mathrm{H}-\mathrm{Tdr}$ and ${ }^{3} \mathrm{H}$-leu when compared to the parallel undiluted sample (Fig. 8A, C). In contrast, the uptake of tritiated substrates by bacterioplankton did not increase over time in the diluted seawater samples from $60 \mathrm{~m}$ and remained lower than the undiluted control samples of the same water (Fig. 8B, D).

At $1 \mathrm{~m}$ only did the abundances of bacteria and dissolved nilrate correlate with total freshwater input on the day before sampling $(p<0.05)$. The production estimates generated using ${ }^{3} \mathrm{H}$-Tdr uptake correlated with those from ${ }^{3} \mathrm{H}$-leu uptake only in $5 \mathrm{~m}(\mathrm{r}=$ $0.751, \mathrm{p}=0.087)$ and $60 \mathrm{~m}\left(\mathrm{r}^{2}=0.815, \mathrm{p}=\right.$ 0.034 ) samples, but not at 1 and $10 \mathrm{~m}$ depths. None of the other variables measured (ACI, abundance, physical and biological factors, or individual carbon source utilization over the whole period or over Days 152 to 201 and 208 to 243 ) were correlated with production estimates from tritiated substrate uptake. How-
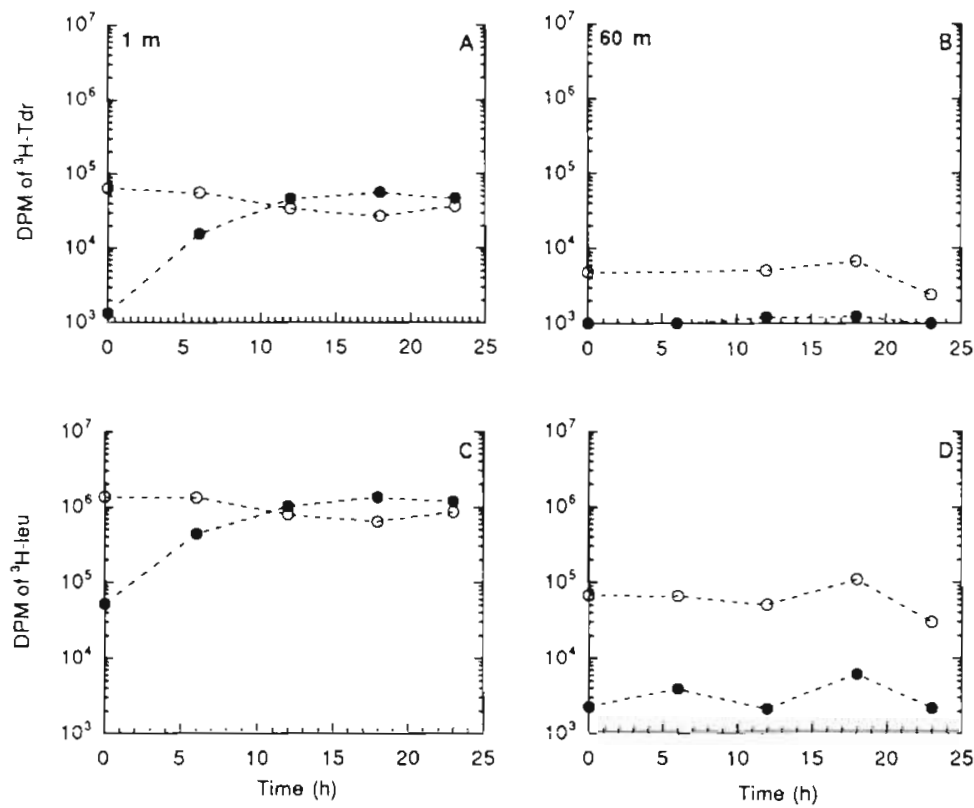

Fig. 8. Relative uptake over 24 h of tritiated thymidine (A and $B$ ) and leucine $(C$ and $D)$ in undiluted seawater $(0)$ and seawater diluted $0.1 \mathrm{v} / \mathrm{v}$ (-) to reduce grazing pressure. Samples from $1 \mathrm{~m}(\mathrm{~A}$ and $\mathrm{C})$ and $60 \mathrm{~m}$ (B and D) are shown ever, ACI was positively correlated with sole carbon source utilization at 1,5 and $10 \mathrm{~m}$ over Days 152 to $201(p<0.05)$, and there were strong trends of similarity between al] 3 indices of bacterioplankton metabolic activity (Figs. 4 to 7 ).

\section{DISCUSSION}

\section{Flow cytometry}

\section{Group I and II cells}

Li et al. (1995) have already used TO-PRO-1 iodide $\mathrm{TM}$ (TP1) and its homodimer, TOTO-1 iodide ${ }^{\text {TM }}$ (TT1), for the enumeration of bacterial cells by flow cytometry; the results obtained were statistically identical to cell counts obtained by direct epifluorescent microscopy. The nucleic acid fluorochromes, TP1 and TT1, are highly sensitive detectors of DNA in eukaryotic cells (Hirons et al. 1994) and bacteria (Li et al. 1995), as well as of extracted double- and single-stranded ribo- and deoxyribonucleic acids (RNA and DNA) in molecular applications (Glazer \& Rye 1992, Selvin 1992). Relative amounts of fluorescence measured by flow cytometry with nucleic acid stains should reflect nucleic acid content (e.g. Robertson \& Button 1989), but little is known about the exact binding characteristics of TP1 and TT1 in nucleic acids and therefore about their relative binding affinities for RNA and DNA under non-saturating conditions. Nuclease digestion experiments performed by Li et al. (1995) indicated that most of the TP1/TT1 staining properties in bacterioplankton could be attributed to DNA, but more recent experiments ( $\mathrm{Li}$ pers. comm.) suggest that RNA also contributes to the fluorescence.

In our previous work (Li et al. 1995) the presence of detectable nucleic acids in both Groups I and II (and their disappearance with nuclease digestion), the relative proportions of the 2 groups over time in cultured bacteria, the low growth rate attributed to Group I cells in natural seawater, and the changing proportions of the 2 groups in bacterioplankton, led us to conclude that Group I cells were inactive rather than cell 'ghosts' as described by Zweifel \& Hagström (1995). More work is clearly required to characterize the exact nature of the 2 groups with respect to their nucleic acid content.

The ratio of fluorescence cell ${ }^{-1}$ between Group I and II bacterioplankton from Bedford Basin suggests that Group II cells contain about 5 times more nucleic acid cell $^{-1}$ than Group I (Figs, $2 \& 3 B$ ). This is consistent with results obtained from bacterioplankton collected in the Atlantic Ocean (Li et al. 1995) and could result partly from the initiation of multiple replication forks during periods of rapid cell growth. such as has been documented in Escherichia coli (Cooper \& Helmstetter 1968). Very little is known about the cell cycle of nucleic acid replication in natural bacterial assemblages or whether and, if so, when these bacteria are capable of generating higher levels of nucleic acids. However, the concurrent production of multiple 
genomes could be a survival strategy for bacteria adapted to rapid biomass expansion in response to scarce, patchy resources.

\section{Pure cultures}

In our experiments with pure cultures, population heterogeneity with respect to nucleic acid content (mean fluorescence) $\mathrm{cell}^{-1}$ was found to be a feature of asynchronous batch culture and appeared to be related to growth stage. While surprisingly little is known about the cell cycle of bacterial metabolism involved in nucleic acid replication, it is clear that flow cytometry of TP1- or TT1-stained bacteria also provides a new opportunity for studying these mechanisms of cell replication and growth.

The ACI

The active cell index is the percent of Group II cells in the total bacterioplankton population. Bacterioplankton from surface samples $(1,5$ and $10 \mathrm{~m})$ showed high (but variable) ACIs (Figs. 2 \& $3 \mathrm{~A}$ and panel $\mathrm{B}$ in Figs, 4 to 6 ) as well as the highest relative nucleic acid content cell ${ }^{-1}$ (Fig. 3B). Bacteria in midwater (30 to $50 \mathrm{~m}$ ) were characterized by lower ACIs (Fig. 2). The ACIs determined from surface and water column samples are consistent with the correlation of Group II abundance with chlorophyll a as reported in Li et al. (1995), and also seem related to fluorescence cell ${ }^{-1}$ (Fig. 3B). Accordingly, the abundance of the Group II cells in a bacterioplankton population seems associated with more productive areas in the Atlantic Ocean such as Bedford Basin, the Grand Banks, and the Moroccan upwelling (Li et al. 1995). However, patterns of microbial productivity measured by radiotracer uptake are not directly correlated with $\mathrm{ACl}$ in this study, indicating that the information obtained is complementary but not identical. Although more work is needed to characterize the 2 TP1/TT1-stained cell groups identified in bacterioplankton by flow cytometry, and to determine the exact contribution of RNA to the fluorescence cell ${ }^{-1}$, it seems that the ACI may be a promising technique for the examination of natural microbial communities as well as to study the cell cycle in pure culture

\section{Substrate utilization in the Biolog plates}

Important findings in this aspect of the study include the identification of the small number of substrates preferred by natural assemblages of bacteria in this environment (Table 2); the important substrates in Bedford Basin are different from those identified at San Francisco Bay and Tomales Bay by Hollibaugh (1994). A major controlling factor in microbial growth is the ability of microorganisms to hydrolyze substrates too complex to be transported through the cell wall (such as polymers) with extracellular enzymes. Results with the Biolog plates indicate that glycerol and glycogen are probably the main targets of exoenzymes in our study area (although glycerol has not previously been reported as such); all other highly-utilized substrates are small molecules like amino acids and small carboxylic acids which should pass freely across the bacterial cell membrane.

Temporal patterns of substrate utilization in water from the surface depths were correlated with ACI and with each other over the $8 \mathrm{wk}$ period when the plates were incubated at $5^{\circ} \mathrm{C}$ (panel $\mathrm{C}$ in Figs. 4 to 7 ). Our longer term study ( 2 years of data collected but not yet analyzed) will show if there are seasonal patterns of Biolog substrate utilization by natural assemblages of bacteria at our study site, and if the presence of large spring or fall phytoplankton blooms in the Bedford Basin enhance the ability of culturable bacteria to hydrolyze larger substrates.

However, several shortcomings of the Biolog method are evident. Growth of bacterioplankton on the individual substrates in the Biolog plates has been interpreted as induction of metabolic pathways in communities whose taxonomic composition is assumed not to have changed (e.g. Garland \& Mills 1991). However, growth of selected members of the bacterioplankton community (i.e. a small number of culturable bacteria) is a more likely possibility and is supported by correlations of patterns of utilization over time at each depth of many of the individual substrates and of the groups of Biolog substrates with each other. Furthermore, recent evidence regarding the adaptability of marine bacterial populations to substrate availability at different temperatures (Li \& Dickie 1987, Shiah \& Ducklow 1994 ) suggests that the long-term incubations required for the Biolog plates may provide results that do not accurately reflect in situ conditions.

\section{Comparison of ACI, Biolog substrate utilization and estimates of bacterial production}

Surface water

Although ${ }^{3} \mathrm{H}-\mathrm{Tdr}$ and ${ }^{3} \mathrm{H}$-leu incorporation methods have yained general acceptance and popular use, they are still highly controversial. They have been exhaustively reviewed and compared experimentally by a number of researchers (e.g. Simon \& Azam 1989, Rie- 
mann \& Bell 1990, Riemann et al. 1990, Riemann \& Azam 1992, Robarts \& Zoharty 1993), who have pointed out a number of potential pitfalls that these methods share. Many of these shortcomings can be directly attributed to the paucity of information on sub. strate utilization and metabolism by heterogeneous natural populations, particularly the lack of information regarding potential variability in species composition succession, and metabolic requirements

During the summer months in Bedford Basin, chlorophyll a concentration did not correlate with bacterial production (as measured by tritiated ${ }^{3} \mathrm{H}$-Tdr and ${ }^{3} \mathrm{H}$ leu uptake), nor with metabolic state as assessed by $\mathrm{ACl}$ and Biolog substrate utilization (Figs, 4 to 7 ). There are, however, many unmeasurable substrate sources such as allochthonous inputs and terrestrial runoff which may affect bacterial production, metabolic state and species composition at this study site. Results from other coastal waters also suggest that chlorophyll $a$ and bacterial production are not necessarily coupled, especially during the summer in temperate waters (e.g. Shiah \& Ducklow 1994) or when other organic substrate sources exceed primary production (Hollibaugh 1994).

An important finding in this study, however, is the similarity in trends between $\mathrm{ACl}$, Biolog substrate utilization, and productivity estimates at 1,5 and $10 \mathrm{~m}$. Some trends appeared to be associated with physical or biological factors, but others could not be attributed to any of the variables measured. For example, the large decrease in $\mathrm{ACl}$, bacterioplankton abundance and Biolog substrate utilization from the surface depths on Day 187 (Figs. 4, 5 \& 6) occurred after a heavy rainfall on Day 186 . This could have been the result of freshwater influx into the Bedford Basin. However, subsequent rainfall events of similar magnitude did not cause coincident decreases in the variables measured. Whatever the underlying influences, the results from the surface depths suggest the ACI can be used as a measure of growth potential, and support the findings of Li et al. (1995) in the open ocean, which showed that samples containing a high ACI were from areas with high levels of primary productivity.

\section{The $60 \mathrm{~m}$ depth}

Interestingly, preferred Biolog substrates were similar for surface and $60 \mathrm{~m}$ samples, suggesting some association of these 2 environments. However, large differences which were observed in chlorophyll a (panel $A$ in Figs. 4 to 7 ), bacterial abundance (panel B in Figs. 4 to 7 ) temperature, and dissolved nutrient levels suggested that the bacterioplankton at $60 \mathrm{~m}$ (in the benthic boundary layer) would be quite different from those at 1,5 and $10 \mathrm{~m}$ (surface) depths. Flow cytometry (ACI) and Biolog substrate utilization, when used with ${ }^{3} \mathrm{H}$ substrate uptake techniques, have enabled us to clearly discriminate between these 2 very different bacterioplankton communities.

If it is assumed that growth is regulated by grazing pressure, the results from the dilution experiment (Fig. 8A-D) suggest that bacteria at $1 \mathrm{~m}$ are actively growing, but those from $60 \mathrm{~m}$ are not. Bacterial productivity estimates derived from the $60 \mathrm{~m}$ population are lower than those from surface water depths (Tables 4 \& 5, panels D and $E$ in Figs. 4 to 7 ), supporting the suggestion of a slower-growing population of bacterioplankton. However, the ACI values observed in bacterioplankton from $60 \mathrm{~m}$ were consistently among the highest in the study (Figs. 2, 3A \& 7B-E), even though the Group II cells also had the lowest fluorescence cell $^{-1}$ of bacterioplankton from any depth measured in the Bedford Basin (Fig. 3B). Results from Li et al. (1995) suggest that a high $\mathrm{ACI}$ may indicate high growth potential, but it appears that the $60 \mathrm{~m}$ bacterioplankton present a different situation. The Biolog substrate utilizations at $60 \mathrm{~m}$, adjusted for differences in initial cell abundances, were roughly twice that from surface water samples (data not shown), suggesting a metabolically very active community of bacteria.

The bacteria from $60 \mathrm{~m}$, and probably those between 55 and $65 \mathrm{~m}$ which are also in the benthic boundary layer (Fig. 2), therefore appear to be a slow-growing population of cells with high metabolic activity when compared to surface and mid-water populations from the same site. There is earlier evidence for a mostly non-growing, but highly-active bacterioplankton population at the sediment-water interface in Halifax Harbour (Novitsky 1987); others (Smith et al. 1986, Griffith et al. 1990) have measured high respiratory rates in the absence of significant bacterial growth in marine samples and suggested they represent low bacterial assimilation efficiencies. Further support for our suggestion of a slow-growing population with high metabolic activity in the benthic boundary layer could be provided using microbial respiration measurements which are being made in Bedford Basin by the authors, as well as from a longer term study over 2 spring bloom periods with the Biolog plates (data as yet unpublished)

\section{Conclusions}

The ACI, calculated from flow cytometry analysis of TP1-stained natural assemblages, is a useful index of bacterial metabolism. Although more work is necessary to characterize Group I and II cells, it is clear that the $\mathrm{ACI}$ can provide information not available through radiotracer experiments. Bacterial activity in natural 
samples is associated with both DNA and RNA content and cell size (Button \& Robertson 1993), as well as cell biomass. With the flow cytometry method, where scatter properties of the cells can be used to estimate size distributions, it would be possible to determine biomass and estimate growth rates using dilution experiments. The Biolog substrate uptake method, although limited by long-term incubations and possible effects of selective culturing, also provides new information, not available from other techniques, on preferred substrates and patterns of substrate use that are related to ACI.

The new applications of the 2 methods used in this study, flow cytometry and the Biolog plates, have distinguished clear differences between bacteria in 2 different communities, i.e. surface waters and the benthic boundary layer of Bedford Basin. Both show clear promise as methods complementary to radiotracer techniques in the assessment of bacterioplankton community metabolic activity.

Acknowledgements. We thank Sarah Kirby for excellent technical assistance and the Canadian Dept of the Environment for data on daily weather conditions during the course of this study

\section{LITERATURE CITED}

Baross JA, Hanus J, Morita RY (1974) Effects of hydrostatic pressure on uracil uptake, ribonucleic acid synthesis and growth of three obligately psychrophilic marine vibrios, Vibrio alginolyticus, and $E$. coli. In: Colwell RR, Morita RY (eds) Effects of the ocean environment on microbial activities. University Park Press, Baltimore, p 180-202

Button DK, Robertson BR (1993) Use of high-resolution flow cytometry to determine the activity and distribution of aquatic bacteria. In: Kemp PF, Sherr BF, Sherr EB, Cole JJ (eds) Handbook of methods in aquatic microbial ecology. Lewis Publishers, Ann Arbor, Ml, p 163-173

Campbell L (1993) Immunofluorescence method for the detection and characterization of marine microbes. In: Kemp PF, Sherr BF, Sherr EB, Cole JJ (eds) Handbook of methods in aquatic microbial ecology. Lewis Publishers, Ann Arbor, MI, p 295-302

Cole JJ, Findlay S, Pace ML (1988) Bacterial production in fresh and saltwater ecosystems: a cross-system overview. Mar Ecol Prog Ser 43:1-10

Cooper S, Helmstetter CE (1968) Chromosome replication and the division cycle in Escherichra coli B/r. J Mol Biol 31 $519-540$

Ducklow HW, Carlson CA (1992) Oceanic bacterial production. Adv Microb Ecol 12:113-181.

Ducklow HW, Kirchman DL, Quinby HL (1992) Bacterioplankton cell growth and macromolecular synthesis in seawater cultures during the North Atlantic spring phytoplankton bloom, May, 1989. Microb Ecol 24:125-144

Garland JL, Mills AL (1991) Classification and characterization of heterotrophic microbial communities on the basis of patterns of community-level sole-carbon-source utilization. Appl Environ Microbiol 57:2351-2359
Glazer AN, Rye HS (1992) Stable dye-DNA intercalation complexes as reagents for high-sensitivity fluorescence detection. Nature 359:859-861

Gorden RW, Hanzen TC, Fliermans CB (1993) Rapid screening for bacteria capable of degrading toxic organic compounds. J Microbiol Methods 18:339-347

Gregory D, Petrie B, Jordan F, Langille P (1993) Oceanographic, geographic and hydrological parameters of Scotia-Fundy and southern Gulf of St. Lawrence inlets. Can Tech Rep Hydrogr Ocean Sci 143

Griffith PC, Douglas DJ, Wainwright SC (1990) Metabolic activity of size-fractionated microbial plankton in estuarine, nearshore, and continental shelf waters of Georgia. Mar Ecol Prog Ser 59:207-217

Hirons GT, Fawcett JJ, Crissman HA (1994) TOTO and YOYO: New very bright fluorochromes for DNA content analysis by flow cytometry. Cytometry 15:129-140

Hollibaugh JT (1994) Relationship between thymidine metabolism, bacterioplankton community metabolic capabilities, and sources of organic matter. Microb Ecol 28:117-131

Li WKW (1990) Bivariate and trivariate analysis in flow cytometry: phytoplankton size and fluorescence. Limnol Oceanogr 35:1356-1368

Li WKW, Dickie PM (1987) Temperature characteristics of photosynthetic and heterotrophic activities: seasonal variations in temporal microbial plankton. Appl Environ Microbiol 53:2282-2295

Li WKW, Dickie PM, Harrison WG, Irwin BD (1993) Biomass and production of bacteria and phytoplankton during the spring bloom in the western North Atlantic Ocean. Deep Sea Res 40:307-327

Li WKW, Jellett JF, Dickie PM (1995) Flow cytometric analysis of marine bacteria stained with TOTO or TO-PRO. Limnol Oceanogr 40:1485-1495

Novitsky JA (1987) Microbial growth rates and biomass production in a marine sediment: evidence for a very active but mostly nongrowing population. Appl Environ Microbiol 53:2368-2372

Riemann B, Azam F (1992) Measurements of bacterial protein synthesis in aquatic environments by means of leucine incorporation. Mar Microb Food Webs 6:91-105

Riemann B, Bell RT (1990) Advances in estimating bacterial biomass and growth in aquatic systems. Arch Hydrobiol 118:385-402

Riemann B, Bell RT, Jørgensen NOG (1990) Incorporation of thymidine, adenine and leucine into natural bacterial assemblages. Mar Ecol Prog Ser 65:87-94

Robarts RD, Zoharty T (1993) Foct or fiction-bacterial growth rates and production as determined by [methy]${ }^{3} \mathrm{H}$-thymidine? Adv Microb Ecol 13:371-425

Robertson BR, Button DK (1989) Characterizing aquatic bacteria according to population, cell size, and apparent DNA content by flow cytometry. Cytometry 10:70-76

Selvin P (1992) The dyer's hand. Science 257:886

Shiah FK, Ducklow HW (1994) Temperature and substrate regulation of bacterial abundance and specific growth rate in Chesapeake Bay, USA. Mar Ecol Prog Ser 103:297-308

Simon M, Azam F (1989) Protein content and protein synthesis rates of planktonic marine bacteria. Mar Ecol Prog Ser 51:201-213

Smith REH, Harrison WG, Irwin B, Platt T (1986) Metabolısm and carbon exchange in microplankton of the Grand Banks (Newfoundland). Mar Ecol Prog Ser 34:171-183.

Zweifel UL, Hagström \& (1995) Total counts of marine bacteria include a large fraction of non-nucleoid-containing bacteria (ghosts). Appl Environ Microbiol 61:2180-2185 